Rev. Col. Bras. Cir.

Vol. 32 - № 2: 56, Mar. / Abr. 2005

\title{
XXVI CONGRESSO BRASILEIRO DE CIRURGIA: CIRURGIA BASEADA EM EVIDÊNCIAS
}

\section{BRAZILIAN CONGRESS OF SURGERY: EVIDENCE BASED-SURGERY}

\author{
José Reinan Ramos-TCBC \\ Presidente da Comissão Científica
}

\begin{abstract}
Organizar o Congresso Brasileiro de Cirurgia é uma tarefa extremamente honrosa, porém árdua e com repercussão difícil de dimensionar. É primordial a harmonia e parceria das comissões científica e organizadora, o apoio e liberdade operacional dados pelo presidente do CBC e a participação efetiva dos cirurgiões de todos os Estados do Brasil. O objetivo final, além da atualização cirúrgica, é aumentar a representatividade do Colégio Brasileiro de Cirurgiões. Os membros do CBC do Rio de Janeiro esperam cumprir com sucesso esta missão.
\end{abstract}

Nesse congresso serão utilizadas técnicas e recursos didáticos consagrados e a estratégia operacional empregada esta sendo vital para arrecadar os recursos financeiros planejados. Estes recursos são fundamentais para a realização adequada desse grande evento e poderá proporcionar a reserva financeira almejada.

A seleção e abrangência dos temas que serão apresentados para mostrar o estado atual da cirurgia, assim como o organograma da programação científica e os convidados internacionais, foram cuidadosamente escolhidos pela Comissão Científica em conjunto com os Presidentes das Comissões Especiais Permanentes, com os Mestres de Capítulos e com os Diretores de Sessões Especializadas.

Os simpósios de especialidades cirúrgicas abrangendo temas de interesse dos especialistas e com ênfase nos debates, terão a participação de convidados internacionais, e a coordenação dos diretores das sessões de especialidades do Colégio Brasileiro de Cirurgiões. Os cursos, objetivando proporcionar informação sobre temas de grande abrangência com discussão dos pontos principais e polêmicos, serão coordenados pelos presidentes das comissões especiais. Os workshops sobre temas mais específicos debatidos em profundidade entre os palestrantes e a platéia serão coordenados pelos membros das comissões especiais ou diretores de sessões. Os consensos e os painéis interativos também terão a coordenação de membros de reconhecida expressão nacional. Resulta daí uma participação direta na realização da programação científica de mais de 50 membros do CBC de todo o Brasil, com mais de 700 cirurgiões participando do programa.

O objetivo principal da comissão foi proporcionar uma discussão dos avanços da cirurgia, baseados em níveis de evidências que produzam uma informação atualizada com grau de recomendação estabelecido.

Além da extensa e atualizada programação científica pretendemos também valorizar a confraternização e reforçar as amizades entre os cirurgiões. Reafirmamos o convite a todos os cirurgiões do Brasil para participarem desta festa fraterna e científica. 